\title{
The Danish Peregrine Falcon population: Reestablishment and eggshell thinning
}

\author{
Niels Peter Andreasen ${ }^{1}$, Knud FalK $^{2 *} \&$ Søren Møller $^{3}$
}

Received: March 23, 2018 - Revised: December 24, 2018 -Accepted: December 25, 2018

This is a contribution submitted to the Proceedings of the World Conference on the Peregrine Falcon in Budapest in September 2017.

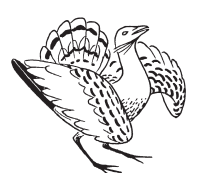

Andreasen, N. P., Falk, K. \& Møller, S. 2018. The Danish Peregrine Falcon population: Reestablishment and eggshell thinning. - Ornis Hungarica 26(2): 159-163. DOI: 10.1515/orhu-2018-0024 vious century, the population gradually declined due to persecution, egg and young collection, and pollution. The last breeding attempt in the $20^{\text {th }}$ century occurred in 1972 in southeastern Denmark. No new breeding attempts were recorded in Denmark until 2001 but since then the population has gradually increased - most rapidly since 2012 - to a peak of 24 territorial pairs in 2018; some of them breeding on man-made structures (nest boxes at bridges and power plants). Here we update the information on the reestablishment of the Peregrine Falcon in Denmark, including origin and dispersal, reproduction, and eggshell thinning.

Keywords: Denmark, recovery, productivity, dispersal, monitoring, eggshell thinning

Összefoglalás Dánia azon országok közé tartozik, ahol nagyon kevés olyan természetes képződmény, sziklaorom található, mely a vándorsólymok (Falco peregrinus) fészkelési igényeinek megfelel. Az elmúlt évszázadban a populáció mérete erősen csökkent a zavarás, tojás- és fiókagyüjtés, valamint a szennyezések következtében. A 20. század utolsó költési kísérlete 1972-ben volt, Délkelet-Dániában. Nem volt megfigyelhető költés egészen 2001ig, amióta azonban a populáció mérete ismét növekedésnek indult - 2012 óta még erőteljesebben - 2018-ban elérve a csúcsot 24 territoriális párral, melyek közül néhány ember által épített helyeken (hidakon és erőműveken) fészkelt. Ebben a tanulmányban tesszük közzé a dán vándorsólyom populáció helyreállításának eredményeit, beleértve az egyedek eredetét és mozgási mintázatait, szaporodásukat és a tojáshéjak vékonyodását.

Kulcsszavak: Dánia, helyreállitás, produktivitás, terjedés, monitorozás, tojáshéj vékonyodás

\footnotetext{
${ }^{1}$ Birdlife Denmark,Ulvshalevej 333 A,DK-4780 Stege,Denmark,e-mail:npa.ulvshale@mail.tele.dk ${ }^{2}$ www.vandrefalk.dk, Ljusstöparbacken 11A, 11765 Stockholm, Sweden, e-mail: knudfalk@hotmail.com

${ }^{3}$ Roskilde University Library, Universitetsvej 1, Postboks 260, 4000 Roskilde, Denmark, e-mail: moller@ruc.dk * corresponding author
}

\section{Introduction}

As reported by Andreasen (2009) the Peregrine (Falco peregrinus) in Denmark suffered from the same effects of environmental pollutants and persecution as the population in the neighbouring countries and was absent as breeding bird from 1972 until 2001 when the first (unsuccessful) clutch of eggs was laid at the classical breeding site, the chalk cliffs of Møns Klint. In this paper, we summarize the recovery and expansion of the population in Denmark, report on the exchange of breeding birds with Sweden, Germany and Poland, and analyse the eggshell thickness as an indicator of the pollutant levels that first led to the extirpation. 


\section{Material and Methods}

Under the auspices of Birdlife Denmark, volunteers have been engaged in various projects to monitor rare and endangered bird species in Denmark; a sub-group have been focusing on the Peregrines under the coordination of the first author. The 'classical' historical breeding sites known from the 1900s have been visited irregularly in the 2000s and, when reoccupied, monitored annually to assess breeding success. Other likely breeding sites, often on man-made structures, have been reported by birders and the public and, when occupied by Peregrines, included in the monitoring scheme.

In roughly half of the successful nesting sites the young have been ringed since 2009 (several sites were inaccessible for various reasons, including landowners, security at power plants); young were aged according to Clum et al. (1996) and colour ringed in coordination with the Nordic Peregrine ringing programmes. Observations of ringed birds reported by photographers, observers and falcon researchers in neighbouring countries etc. has made it possible to determine the origin of several breeding Peregrines in Denmark and abroad.

In nests visited for ringing, the nest scrape was carefully searched for eggshell fragments deriving from the hatched eggs; all fragments were collected and later measured and analysed according to the procedures described by Falk et al. (2006) and Vorkamp et al. (2017).

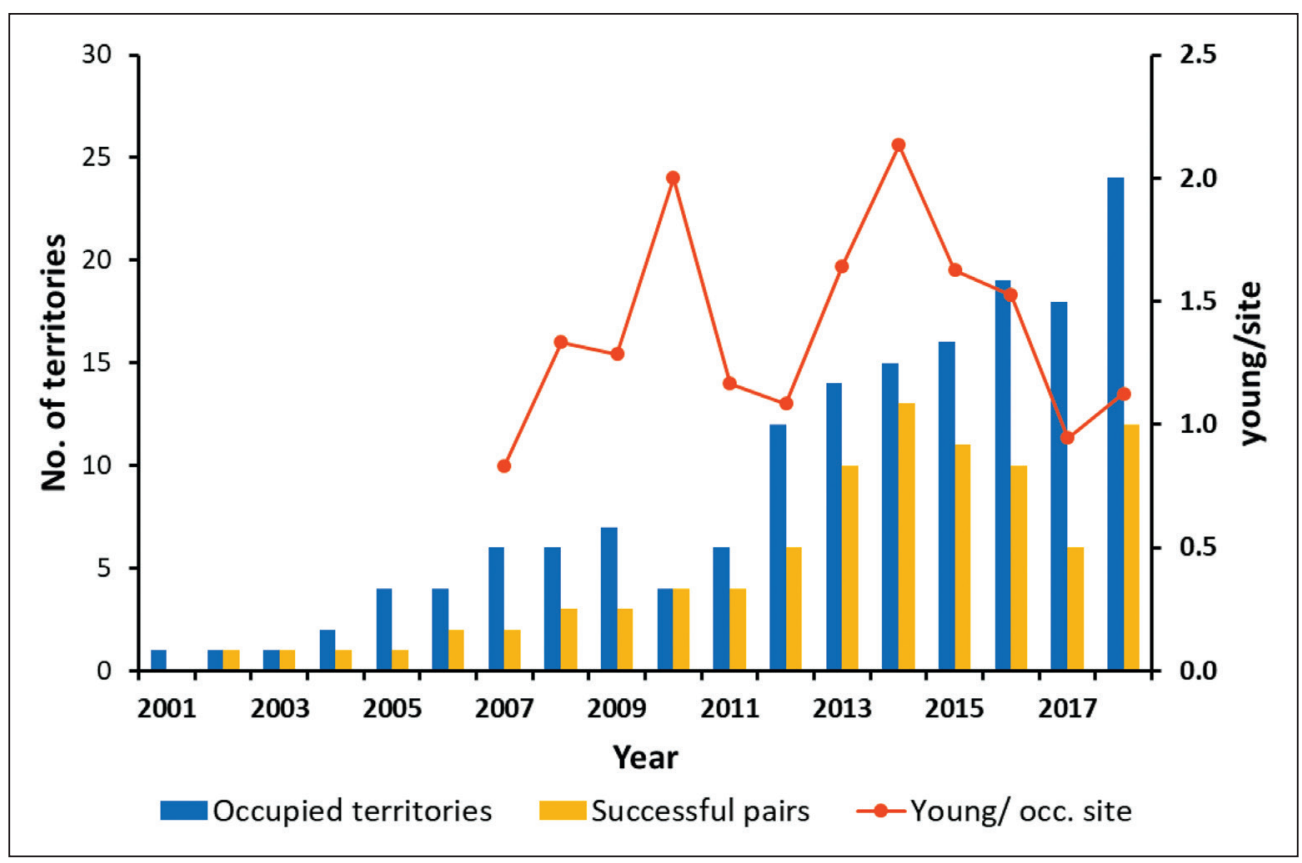

Figure 1. Population increase and productivity in the Danish Peregrine Falcon population 2001-2018 1. ábra A dániai vándorsólyom populáció növekedése és produktivitása 2001 és 2018 között 


\section{Results and Discussion}

Since the Peregrine returned to Denmark and started breeding by 2001, the population has increased to a peak of 24 territorial pairs in 2018 with up to 13 (in 2014) successfully producing young (Figure 1). The apparent dip in 2010-11 may have been caused by less thorough field surveys. Since 2007 more than 5 sites have been occupied and on average $60 \%$ have been successful.

Andreasen (2009) estimated that the Danish breeding population in the past centuries probably was around 6-8 pairs/year on average, maximum $10-15$ pairs, so the population can be considered to be fully recovered and now beyond historical levels which, however, was probably artificially low, i.e. below environmental carrying capacity, due to centuries of persecution (Andreasen 2008).

Denmark is largely a flat country so a typical cliff-nester as the Peregrine mainly have access to suitable breeding sites at the few chalk and limestone cliffs in eastern Denmark, on the rocky coasts and stone quarries of the island Bornholm and, increasingly, on man-made
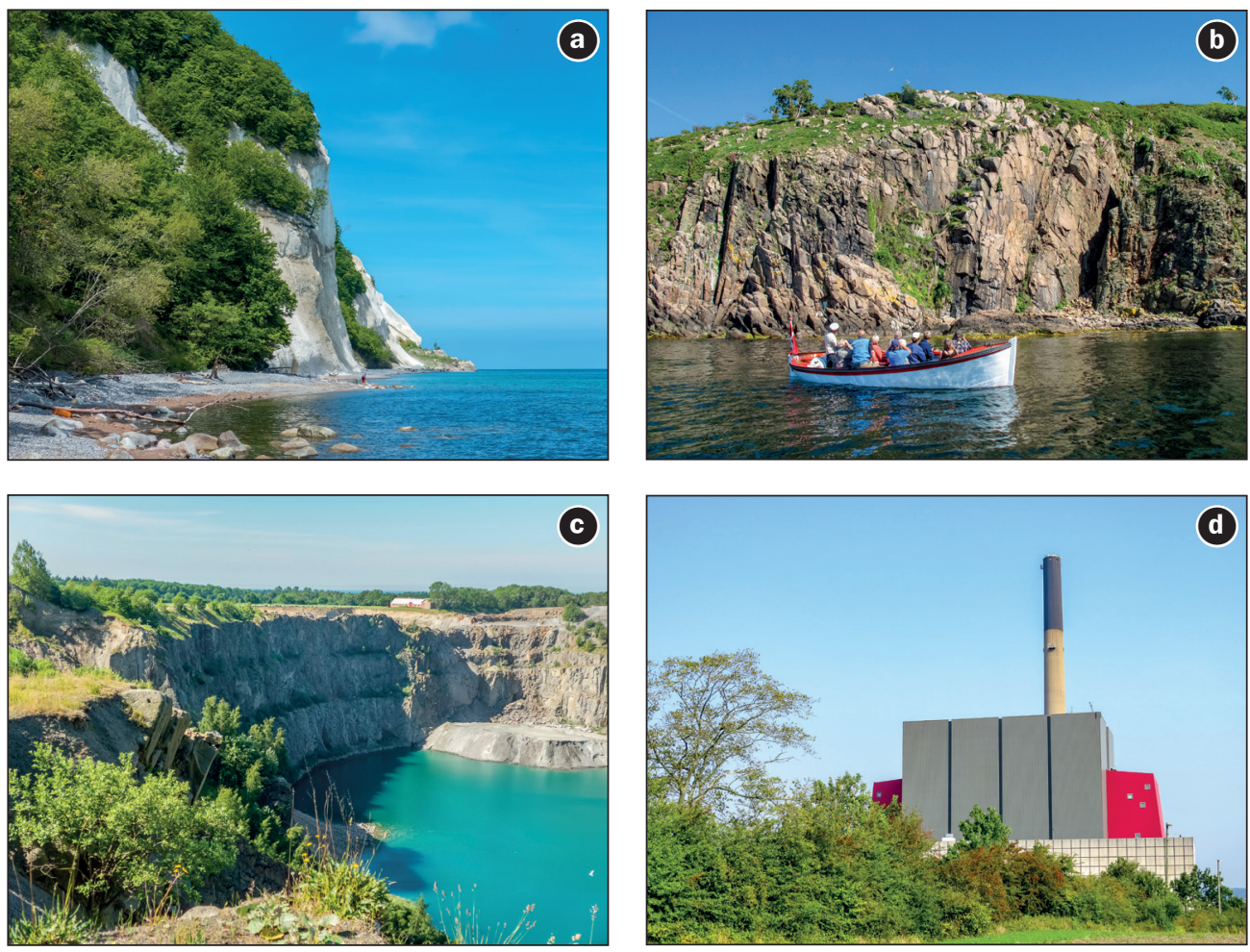

Figure 2. Example of Peregrine breeding sites in Denmark: limestone cliffs such as Møns Klint (a), rocky coastal cliffs (b) and stone quarries (c) at the isle of Bornholm (only part of Denmark with bedrock) and man-made structures like Ensted power plant (d)

2. ábra Példák a vándorsólyom fészkelőhelyeire Dániában: mészkőszirtek, mint a Mana Klint (a), sziklás partoldalak (b) és kőfejtők (c) Bornholm szigetén, valamint mesterséges épületek, mint az Ensted erőmű (d) 
structures like tall power plants or bridges (Figure 2) similar to the population in the Czeck Republic, where industrial structures, not city centre buildings, are main man-made breeding sites (Beran et al. 2018). With less persecution of raptors compared to decades ago, manmade structures may offer opportunities for an expanding breeding population; several tall buildings in cities hold wintering Peregrines (according to citizen science database, Birdlife Denmark) and, at some point, may turn into breeding sites.

Average productivity (2007-18 - excluding the early years with less than 5 occupied sites) was 1.4 young/occupied site (range 0.8 to 2.1 ), or 2.4 young/successful pair (Figure 1). The productivity of Danish Peregrines is thus well above the critical limit (1.0 young/occupied site, USFWS 2003) where concerns may be raised. Based on backdating from the age of young when they were ringed, the average hatching date of first egg in 36 clutches was May $8(\mathrm{SD}=14.4)$.

Ringed Peregrines originating from neighbouring countries have in 11 cases been observed breeding in Denmark (Figure 3): three from Sweden, six from Germany and two from Poland. Similarly, Peregrines ringed in Danish nests have been observed as territorial or breeding in Sweden (two cases) or at other locations in Denmark (five cases). Hence, the recovery of the Danish population relies on the reestablishment of healthy populations in neighbouring countries - and the ringing recoveries verify continued exchange and gene flow within the region.

Not much is known about contaminant loads in Danish Peregrines in the past. One of the eggs from the breeding attempt in 1970 was analysed for DDT and PCB and the result showed very high values, comparable to those known from England and Germany (Andreasen 2012).

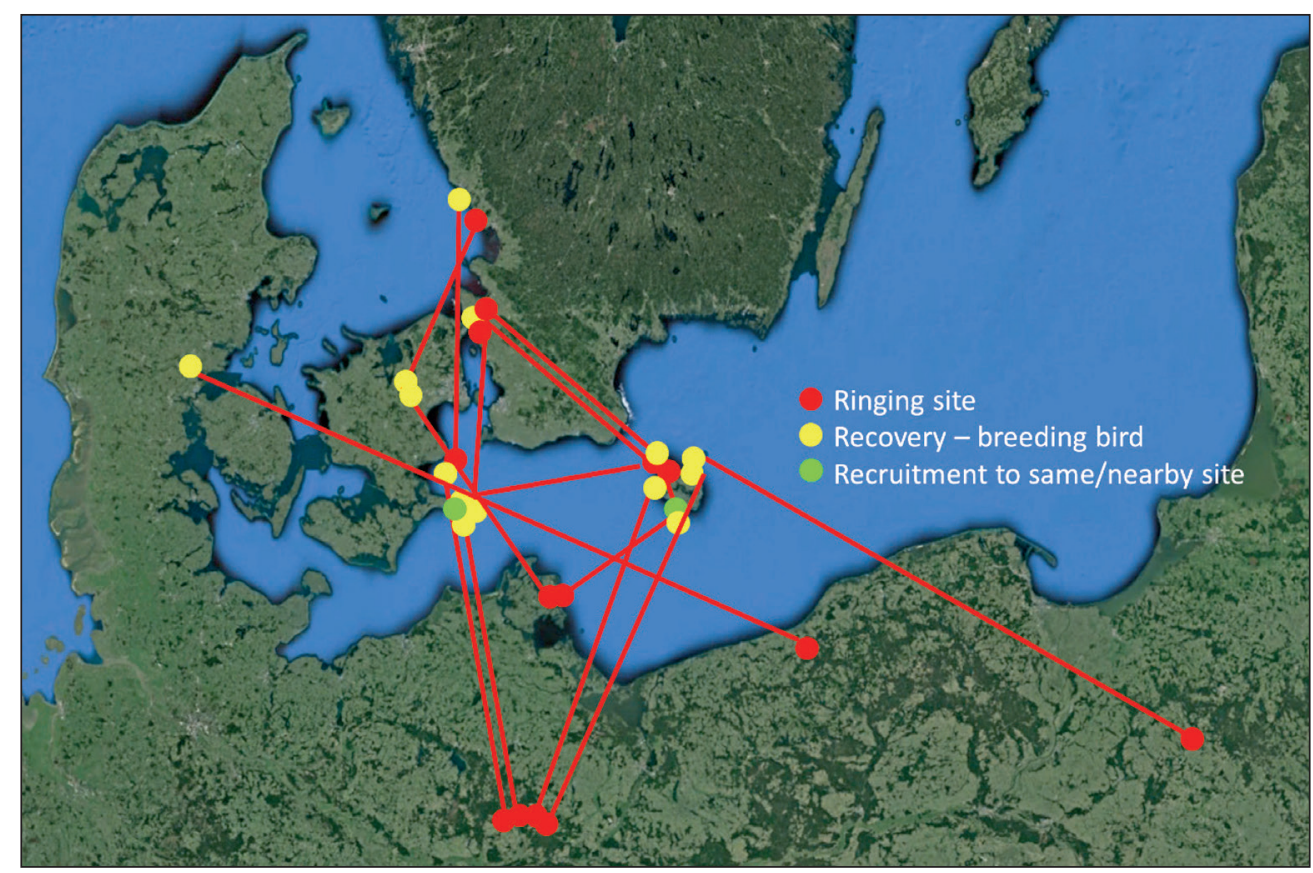

Figure 3. Origin and dispersal of ringed Peregrines from/to the breeding population in Denmark 2001-2018 (map source: Google Earth)

3. ábra A gyűrűzött vándorsólymok jelölési helyei és útvonalai a dán költőpopulációból 2001 és 2018 között (térkép forrása: Google Earth) 
The eggshell fragments collected in 11 successful Danish nests 2009-16 had on average normal thickness when compared to pre-DDT eggs available at Zoological Museum, Natural History Museum of Denmark $(0.335 \mathrm{~mm}, \mathrm{SD}=0.0181, \mathrm{~N}=11)$. The pre-DDT eggs used for comparison also had a thickness of $0.335 \mathrm{~mm}, \mathrm{SD}=0.0183, \mathrm{~N}=16$ (Falk \& Møller 1990). This indicates that the load of eggshell thinning contaminants, especially DDT and its degradation products, in the Peregrines is low and no longer of concern. This is consistent with findings from Germany where Peregrine Falcon shell thinning was back to normal 30 years after the legal ban of DDT in 1972 (Wegner et al. 2005), in contrast to some populations in the Nearctic where normal shell thickness is still decades away (Falk et al. 2018).

\section{Acknowledgements}

We thank the many volunteer ornithologists for providing observations, photographs etc. to monitor the population recovery in Denmark. The coordination has been supported by grants from Birdlife International; the ringing program is approved, coordinated and performed by Copenhagen Bird Ringing Centre, Natural History Museum of Denmark.

\section{References}

Andreasen, N. P. 2008. Genindvandring af Vandrefalk Falco peregrinus som dansk ynglefugl [The return of the Peregrine Falcon Falco peregrinus as a breeding bird in Denmark]. - Dansk Ornitologisk Forenings Tidsskrift 100: 309-218. (in Danish with English Summary)

Andreasen, N. P. 2009. Distribution and present status of the Peregrine Falcon (Falco p. peregrinus) in Denmark. - In: Sielicki, J. \& Mizera, T (eds.) Peregrine Falcon populations - status and perspectives in the $21^{\text {st }}$ century. - Turul, Warsaw and University of Life Sciences, Poznań, pp. 8-10.

Andreasen, N. P. 2012. I al sin vilde skønhed [In its wild beauty]. - DesignMark, Virum (in Danish)

Beran, V., Vrána, J. \& Horal, D. 2018. Population trends and diversification of breeding habitats of Peregrine Falcon (Falco peregrinus) in the Czech Republic since 1990. - Ornis Hungarica 26(2): 121-129. DOI: 10.1515/ orhu-2018-0020

Clum, N., Harrity, P. \& Heck, W. 1996. Aging young Peregrines. - In: Cade, T. J., Enderson, J. H. \& Linthicum, J. (eds.) Guide to Management of Peregrine Falcons at the Eyrie. - The Peregrine Fund: Boise, pp. $37-63$.

Falk, K. \& Møller, S. 1990. Clutch size effects on eggshell thickness in the Peregrine Falcon and European Kestrel. - Ornis Scandinavica 21: 265-269.

Falk, K., Møller, S., Rigét, F. F., Sørensen, P. B. \& Vorkamp, K. 2018. Raptors are still affected by environmental pollutants: Greenlandic Peregrines will not have normal eggshell thickness until 2034. - Ornis Hungarica 26(2): 171-176. DOI: 10.1515/orhu-2018-0026

Falk, K., Møller, S. \& Mattox, W. G. 2006. A long-term increase in eggshell thickness in Greenlandic Peregrine Falcons Falco peregrinus tundrius. - Science of Total Environment 355: 127-134. DOI: 10.1016/j.scitotenv.2005.02.024

Vorkamp, K., Falk, F., Møller, S., Rigét, F. F., Bossi, R. \& Sørensen, P. B. 2017. New and updated time trends of persistent organic pollutants and their effects on eggs of Peregrine Falcons (Falco peregrinus) from South Greenland. - Aarhus University, DCE - Danish Centre for Environment and Energy, pp. 80, Scientific Report from DCE - Danish Centre for Environment and Energy No. 249 http://dce2.au.dk/pub/SR249.pdf

USFWS 2003. Monitoring plan for the American Peregrine Falcon, a species recovered under the endangered species act. - U.S. Fish and Wildlife Service, Divisions of Endangered Species and Migratory Birds and State Programs, Pacific Region, Portland, OR.

Wegner, P., Kleinstäuber, G., Baum, F. \& Schilling, F. 2005. Long-term investigation of the degree of exposure of German Peregrine Falcons (Falco peregrinus) to damaging chemicals from the environment. - Journal of Ornithology 146(1): 34-54. DOI: 10.1007/s10336-004-0053-6 